\title{
Nya böcker
}

\author{
Alkohol-och narkotikaproblem \\ Björn Johnson, Torkel Richert \& Bengt Svensson (2017) \\ Lund: Studentlitteratur
}

Denne bog har et ambitiøst formål: at afdække og diskutere forbrug, forebyggelse, behandling og policy i relation til alkohol og narkotika i Sverige. Læsere kan således blive klogere ikke blot på ét aspekt af eller ét perspektiv på alkohol og narkotika. Bogen giver nemlig et nuanceret billede af, hvilke komplekse fænomener og udfordringer vi står med både som samfund og som individer, når det gælder alkohol og narkotika. Bogen er også ambitiøs idet den fokuserer på både alkohol og narkotika. Dette giver god mening eftersom Sverige har en fælles national strategi for arbejdet med alkohol, narkotika, doping og tobak (kaldet ANDT-strategien), samtidig med at der er forskellige politiske mål for hhv. alkohol og narkotika. Dette dobbelte fokus giver et godt grundlag for at sammenligne og stille forskelle og ligheder op mellem hhv. et legalt rusmiddel og illegale rusmidler. Ved at dække begge forskningstraditioner i bogen tager forfatterne således også en udfordring op, eftersom forskningslitteraturen generelt fokuserer enten på alkohol eller narkotika, sjældent på begge.

Bogen består af 12 kapitler. Det første kapitel er en introduktion til bogen. Det sidste er et bud på, hvad der kan eller bør fokuseres på og debatteres fremover. De fleste kapitler tager fat på et samfundsmæssigt aspekt omkring alkohol og narkotika, som politik og lovgivning på området eller behandling, forebyggelse og skadesreduktion. Andre kapitler fokuserer på forbrug af rusmidler, rusmidlers effekter og skadevirkninger eller på hvad misbrug og afhængighed betyder på et individuelt niveau og for den enkelte rusmiddelbruger. Der er virkelig meget information at hente i kapitlerne og selvom bogen tager udgangspunkt i Sverige og svenske forhold, så sætter forfatterne også de svenske forhold $i$ en international kontekst, $\mathrm{fx}$ i forhold til politik på området og hvordan både FN konventioner og EU strategier har betydning for national alkohol- og narkotikapolitik; hvilke skadesreducerende indsatser der mere generelt findes, men som ikke er tilstede i Sverige; eller hvilke forskellige teoretiske modeller, der findes, til at forklare rusmiddelproblemer med. 
Hvert kapitel er bygget op omkring hhv. et afsnit hvor forskningsresultater og/eller teoretiske perspektiver fremlægges efterfulgt af et interview med én, der har beskæftiget sig i sit arbejde med alkohol- og narkotikarelaterede problemstillinger. Fx er der, som en del af kapitel 4 der fokuserer på hvordan man kan forklare rusmiddelproblematikker, et interview med Jonas Stålheim, der er psykolog i en behandlingsklinik (Linnéteamet) i Göteborg. Efter kapitel 7, der handler om alkohol og narkotikakontrol, er der et interview med Richard Fagerberg, som er politiinspektør i Göteborg. Og efter kapitel 11, der handler om skadesreducerende indsatser, er der et interview med infektionslæge Marianne Alanko Blomé, der arbejder i sprøjtebytteprogrammet i Malmö. Disse interviews giver en indsigt i hvordan det aspekt, der har været fokus på i det enkelte kapitel, arbejdes med i praksis. Det er de enkelte fagpersoners perspektiver, der er i fokus og dermed præsenteres der også en anden form for viden end i selve kapitlet. Det er afvekslende og forfriskende, og man kunne som læser starte med at læse alle interviewene og dernæst dykke ned i kapitlernes tekst efterfølgende. Hvis man er ny på feltet og gerne vil starte med noget lidt lettere tilgængeligt for at danne sig et overblik over hvilke forskellige typer af indsatser, der findes på området i Sverige og lidt historik omkring de enkelte former for indsatser, er en læsning af interviewene en spændende introduktion til dette.

Når man ser på forfatternes baggrund, så giver det også god mening at de har fået denne idé at inkludere interviews med fagprofessionelle i bogen. Alle tre forfattere er forskere i socialt arbejde, selvom de kommer fra forskellige faglige baggrund. Alle arbejder med empirisk forskning og har selv interviewet eller på anden måde været i kontakt med alkohol- og narkotikabrugere, behandlere, socialarbejdere, politi, politikere eller lignende aktører i alkohol- og narkotikafeltet som en del af deres forskning. Og to af forfatterne har erfaringer fra at arbejde med klienter med et rusmiddelproblem i hhv. behandlingssektoren og som socialrådgiver i kommunalt regi før de blev forskere.

Det er ikke muligt at gå i dybden med alle de spændende aspekter, diskussioner og perspektiver som de 12 kapitler præsenterer. Men de fleste kapitler giver både en begrebsafklaring ( $\mathrm{fx}$ af misbrug, afhængighed, problematisk forbrug, eller skadesreduktion), har et historisk perspektiv, beskriver forskellige teoretiske eller politiske positioner i feltet, eller beskriver forskellige former for indsatser ( $\mathrm{fx}$ behandlingstyper, skadesreduktions initiativer, eller forebyggelsesindsatser). En stor styrke ved så detaljeret en bog som denne er, at den har et index/sakregister man kan slå op i. Ønsker man at læse om noget særligt er det således nemt at finde.

Der er også i de fleste kapitler en kritisk eller i alt fald spørgende tilgang til de indsatser og politikker som findes i Sverige på alkohol og narkotikaområdet. Ligesom der i forordet diskuteres hvorfor forfatterne landede på 'narkotika' i stedet for 'droger' eller 'rusmedel' som gennemgående begreb. Men de kritiske refleksioner kunne 
have været mere tydelige. Fx kan det undre at bogens titel fremhæver 'problem'. Forfatterne beskriver selv i kapitel 1 at det er 'kontroverserne' omkring alkohol og narkotika, der til stadighed fascinerer dem og driver deres forskning og de fokuserer $i$ flere kapitler på forbrug af både alkohol og narkotika, samt på rusens positive sider, ikke blot af legale rusmidler som alkohol, men også brugere af illegale rusmidlers positive rusoplevelser. Og selvom de skriver at de håber bogen vil vække læseres interesse og engagement for de mennesker der har et problem med alkohol og narkotika, så synes bogen at kunne tilbyde en langt bredere indsigt i, hvordan de måder vi forholder os til alkohol og narkotika på som samfund er med til at definere medborgerskab, rettigheder, livsbaner og muligheder for den enkelte alkohol- eller narkotikabruger, forskellige indsatsers modsatrettede formål (fx narkotikakontrol og stofindtagelsesrum) og dermed potentielt indebærer at de forskellige indsatser i en narkotikastrategi modarbejder hinanden, osv. Men måske forfatterne har en pointe med ikke at gøre disse diskussioner eller kritikker alt for eksplicitte og snarere lægge op til at vi som læsere selv engagerer os i de debatter. Det sidste kapitel om fremtidens udfordringer er baseret på afsnit der er struktureret som spørgsmål, som $\mathrm{fx}$ Hvilke udfordringer findes der i relation til kontrol, forebyggelse og behandling? Eller Hvilken rolle skal skadesreducerende indsatser have? Herefter opsummerer forfatterne pointerne fra de foregående kapitler og vi får dermed som læsere et overblik over kompleksiteten i det felt som bogen omhandler. Aller bagest i bogen findes 26 spørgsmål, som fx undervisere kunne præsentere for studerende, på uddannelser, hvor alkohol- og narkotikafænomener og -problematikker er centrale. Alle spørgsmål lægger op til at sammenstille ofte forskellige eller modsatrettede positioner i feltet og de lægger således alle op til debat, snarere end at fokusere på bestemte svar.

Læser man denne bog - enten som studerende eller som interesseret lægperson - vil man således formodentlig ikke kunne undgå at få sat alkohol- og narkotikaproblematikker til debat. Enten med andre eller med sig selv og sine egne holdninger. Og det er en meget fin kvalitet ved denne bog.

\section{Vibeke Asmussen Frank}

Professor, Center for Rusmiddelsforskning, Aarhus universitet. 